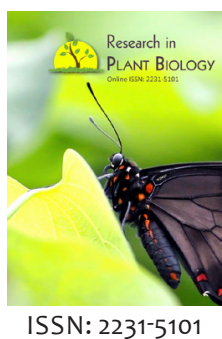

Received: October 08, 2021 Revised: December 25, 2021 Accepted: December 27, 2021 Published: December 30, 2021

*Corresponding Author: Akinwumi Johnson Akinloye E-mail: akinloye johnson@ yahoo.com

\section{Wood anatomical features of some Nigerian species of Acacia Mill and their suitability for paper making}

\author{
Seun Mercy Owolabi', Monday Daniel Odiye', \\ Akinwumi Johnson Akinloye ${ }^{2 *}$, Abiodun Emmanuel Ayodele' \\ 'Department of Botany, University of Ibadan, Ibadan, Oyo State, Nigeria, ${ }^{2}$ Department of Botany, Obafemi \\ Awolowo University, Ile-Ife, Osun State, Nigeria
}

\begin{abstract}
A comparative wood anatomical study of six species of the genus Acacia commonly found in Nigeria was carried out. Wood samples were collected from matured branches of plants in different locations in Mazah and Shere Hills, Jos, Plateau State, Nigeria. Transverse, tangential and radial longitudinal sections as well as wood macerates were prepared and mounted unto microscopic slides using standard anatomical methods. All the species had diffused porous wood, heterogeneous rays, aseptate fibres and predominantly solitary vessels with simple perforation plate, few pore clusters and pore multiples. Banded paratracheal axial parenchyma was common in all taxa except in A. senegal which was predominantly paratracheal without bands. Multiseriate rays were common features in all taxa except in A. nilotica which had predominantly uniseriate rays. Quantitative wood anatomical characters such as fibre length, fibre diameter, fibre lumen diameter, fibre wall thickness, vessel length, vessel diameter, ray length, ray diameter and pore diameter were of taxonomic importance in the delimitation of the studied taxa. The Runkel ratio of A. senegal $(0.99 \mu \mathrm{m})$ compared favourably with some hardwood species in the Nigerian rainforest ecosystem hence this taxon could be exploited for pulp and paper in Nigeria.
\end{abstract}

KEYWORDS: Acacia, anatomy, features, fibre, paper, pulp, taxonomy, wood

\section{INTRODUCTION}

The genus Acacia Mill. (Mimosoideae - Fabaceae) comprises about 1,380 species (Saini et al., 2008) indigenous to tropical and subtropical savannas mainly in Australia and Africa (Cronquist, 1981). Most species of Acacia occur in regions where the rainfall is markedly seasonal or low; only few inhabit the rainforest areas. Many phytochemicals have been reported in Acacia, such as hydrolysable and condensed tannins, flavonoids, terpenes, alkaloids, cyanogenic glycosides and gums (Malan \& Roux, 1975; Secor et al., 1976; Flath et al., 1983; Bennie et al., 2001; Seigler, 2003). The wood of A. nilotica (L.) Willd. ex. Del. is suitable for carved and turnery products (Krisdianto \& Damayanti, 2007). Gums from the slashed trunk of A. senegal (L.) Willd. and A. seyal Del. are known to be of great economic importance in confectionery, in the clarification of wine as with all adhesives, and as thickener, stabilizer or emulsifier in a wide variety of foodstuffs.

The existing classification of Acacia species has been based mainly on their macro-morphological characters; classification based on or incorporating wood anatomical characters is quite rare. Despite the economic importance of the species, there is paucity of information on the anatomical features of the Nigerian taxa. Therefore, the aim of this study is to assess the wood micro-characters of the six common Acacia species in Nigeria (A. dudgeoni Craib ex Holl., A. hockii De Willd., A. nilotica, A. senegal, A. seyal and A. sieberiana DC) for their taxonomic importance and determine the suitability of the taxa for pulp and paper production.

\section{MATERIALS AND METHODS}

Specimens of five of the six Acacia species were studied at the University of Ibadan Herbarium (UIH), Ibadan (Table 1) while specimens of A. senegal were studied at the Forest Herbarium (FHI) of the Forestry Research Institute of Nigeria, Ibadan, Oyo State. Fresh wood was collected from matured branches of Acacia dudgeon, A. hockii, A. nilotica, A. senegal, A. seyal, and A. sieberiana from different locations in Mazah and Shere Hills, Jos, Plateau State (Table 2). The identification and authentication were done at the Forest Herbarium (FHI), Ibadan. The wood samples were preserved in $50 \%$ ethanol for further use. 
Table 1: Representative Herbarium specimens of Acacia species examined

\begin{tabular}{|c|c|c|c|c|}
\hline & $\begin{array}{l}\text { Keana, Lafia Division, Benue. Plateau } \\
\text { State. }\end{array}$ & J.B. Hall & UIH 16439 & $03-1975$ \\
\hline \multirow[t]{4}{*}{ A. hockii } & Tula near cone shaped Hill, Gombe. & J. Lowe & UIH 11401 & 19-02-1969 \\
\hline & Mile 71/2 Jos Bauchi. & J.A.D. Jackson & UIH 13513 & 03-09-1967 \\
\hline & Borgu G.R., Wawa-Luma road mp 180. & C. Geerling & UIH 18349 & $14-11-1978$ \\
\hline & 23 miles, Bauchi. & J. Lowe & UIH 11209 & 12-11-1968 \\
\hline \multirow[t]{3}{*}{ A. Senegal } & UI Botanical Gardens, Ibadan & D. P. Stanfield and M.G. Latilo & FHI 47792 & $3-2-1964$ \\
\hline & Awun Forest Reserve, Jebba & $\begin{array}{l}\text { H. D. Oyeachusim, } \\
\text { T. K. Odewo and J. Olorunfemi }\end{array}$ & FHI 101441 & $13-6-1964$ \\
\hline & Bakure Tureta Forest Reserve, Sokoto & H. D. Onyeachusim & FHI 44071 & $17-2-1960$ \\
\hline \multirow[t]{2}{*}{ A. nilotica } & New site, Bayero University Kano. & J. Lowe & UIH 20474 & 28-12-1984 \\
\hline & West Kaniya gyade, Bauchi State. & E.0. Awosina & UIH 21151 & 12-01-1987 \\
\hline A. seyal & Shendam Division BP State. & W.J. Howard & UIH 15712 & 18-09-1973 \\
\hline A. sieberiana & $\begin{array}{l}2 \text { miles from Wawa on Wawa to New } \\
\text { Bussa Road. }\end{array}$ & $\begin{array}{l}\text { A. D. Onyeachusim } \\
\text { and A. Binuyo }\end{array}$ & UIH 12422 & $08-03-1966$ \\
\hline Acacia dudgeon & $\begin{array}{l}\text { Proposed grazing/reserve area near Bin } \\
\text { Yauri, Sokoto. }\end{array}$ & J.B. Hall & UIH 14021 & 05-09-1972 \\
\hline
\end{tabular}

Table 2: Locations of collections of Acacia species used for the study

\begin{tabular}{|c|c|c|c|c|c|}
\hline Taxon & Locality & Collector (s) & Collector Number & Date of collection & GPS Reading \\
\hline Acacia dudgeon & Mazah Hills, Gwong, Jos & Owolabi/Chukwuma & 056 & 5 November, 2015 & $9^{0} 55^{\prime} \mathrm{N}$ and $8^{\circ} 55^{\prime} \mathrm{E}$ \\
\hline A. hockii, & Mazah Hills, Gwong, Jos & Owolabi/Chukwuma & 067 & 5 November, 2015 & $9^{0} 55^{\prime} \mathrm{N}$ and $8^{0} 55^{\prime} \mathrm{E}$ \\
\hline A. Senegal & Shere Hills, Jos & Owolabi/Chukwuma & 048 & 8 November, 2015 & $9^{0} 57^{\prime} \mathrm{N}$ and $9^{0} 3^{\prime} \mathrm{E}$ \\
\hline A. nilotica & Shere Hills, Jos & Owolabi/Chukwuma & 074 & 8 November, 2015 & $9^{\circ} 57^{\prime} \mathrm{N}$ and $9^{\circ} 3^{\prime} \mathrm{E}$ \\
\hline A. seyal & Shere Hills, Jos & Owolabi/Chukwuma & 023 & 8 November, 2015 & $9^{0} 57^{\prime} \mathrm{N}$ and $9^{0} 3^{\prime} \mathrm{E}$ \\
\hline A. sieberiana & Mazah Hills, Gwong, Jos & Owolabi/Chukwuma & 068 & 5 November, 2015 & $9^{0} 55^{\prime} \mathrm{N}$ and $8^{\circ} 55^{\prime} \mathrm{E}$ \\
\hline
\end{tabular}

Sectioning: Wood blocks of approximately $10 \times 10 \times 10 \mathrm{~cm}$ was obtained from the wood samples of the matured branches of each plant species and small blocks were cut into cubes of $8 \mathrm{~cm}^{3}$. The blocks were boiled in $5 \%$ aqueous solution of Sodium hydroxide $(\mathrm{NaOH})$ to soften the wood. Transverse sections (TS), tangential longitudinal sections (TLS), and radial longitudinal sections (RLS) of the wood samples were cut at 10 microns thickness using Reichert Austria sledge microtome and were preserved in $50 \%$ ethanol prior to staining. Each section was stained for 5 minutes in Safranin $\mathrm{O}$, then rinsed in water thrice to remove excess stain and counter stained in Alcian blue for another 5 minutes. The counter-stained sections were rinsed in water thrice before passing them through treatment in series of ethanol solutions $(50 \%, 70 \%, 80 \%, 90 \%$ and $100 \%)$ to remove water molecules (dehydration process) and to remove excess stain (differentiation process). The dehydrated and differentiated sections were cleared in ethanol and xylene mixtures in series (ethanol/xylene, 50/50, 40/60, 30/70, 20/80, $10 / 90$ and absolute xylene). Each section was mounted on a clean glass slide in DPX (mountant).

Maceration: Wood samples of each Acacia species were sliced into small pieces using pen knife and macerated using Schulz's fluid obtained by mixing equal volume of chromic acid [dissolved lgm of Potassium Nitrate $\left(\mathrm{KNO}_{3}\right)$ in $50 \mathrm{ml}$ of Concentrated Nitric acid $\left.\left(\mathrm{HNO}_{3}\right)\right]$ and $10 \%$ trioxonitrate $\mathrm{V}$ acid. The maceration was carried out in a beaker heated on a hot plate in the fume cupboard for 40 minutes. This treatment removed the middle lamella to free the cells and their constituents. The macerated wood samples were washed in several changes of water and preserved in $50 \%$ ethanol prior to staining with Safranin $\mathrm{O}$ for 5 minutes and then carefully rinsed in water once. Macerates were mounted in $25 \%$ glycerol on clean slides with the edges of the cover slips sealed with nail varnish.

Microscopy: Microscopic observations of prepared slides of the sections and macerates were done using LEICA DM500 binocular light microscope. Wood characters studied included xylem vessels, axial parenchyma cells, fibres, rays, tyloses, secretory ducts/canals and crystals. Photomicrographs of the slides showing anatomical features of the wood were taken using Accu-scope trinocular microscope with 3.2 MP CMOS digital camera.

The following parameters were measured using the stage and eye piece micrometers:

1. Fibre length and width, lumen and wall thickness in the macerates

2. Vessel pore diameter at the Transverse Section (TS), vessel length and vessel width in the macerates.

3. Ray height and width at the T.L.S. plane

The characters studied in wood macerates were used to derive the anatomical properties and morphological indices such as the Runkel ratio, slenderness ratio, flexibility coefficient, fibre length (FL), fibre diameter (FD), fibre lumen diameter (FLD), fibre wall thickness (FWT), vessel diameter (VD), vessel length (VL), ray height $(\mathrm{RH})$, ray diameter (RD), and pore diameter (PD)

The Fibre wall thickness was obtained with the formula:

Fibre wall thickness $($ FWT $)=\frac{\text { FD }- \text { FLD }}{2}$

Where $\mathrm{FD}=$ Fibre diameter and $\mathrm{FLD}=$ Fibre lumen diameter 
The Runkel ratio was obtained with a formula:

$$
\mathrm{RR}=\frac{2 \mathrm{FWT}}{\mathrm{FLD}}
$$

Where RR= Runkel Ratio

Flexibility coefficient $=\frac{\mathrm{FLD}}{\mathrm{FD}} \times \frac{100}{1}$

Where FLD $=$ Fibre lumen diameter, $\mathrm{FD}=$ Fibre diameter

And Slenderness ratio $=\frac{\mathrm{FL}}{\mathrm{FD}}$

Where FL= Fibre length, $\mathrm{FD}=$ Fibre diameter

All data were subjected to Cluster Analysis using SPSS version 20. Descriptive terminologies and measurements were in accordance to the International Association of Wood Anatomists (IAWA) list of Microscopic Features for Hardwood Identification (IAWA, 1989).

\section{RESULTS}

\section{Wood Anatomical Description of the Studied Taxa}

Acacia dudgeoni (Figures 2A, 3A, 4A \& 5A)

Wood porosity: Diffuse porous

Vessels: Solitary vessels dominant, radial pore multiple ranged from 2-4 and pore clusters from 2 - 4. Pore shape at transverse plane circular, oval, cylindrical and arch; tyloses present in some vessels. Mean vessel length was $216.4 \pm 80.5 \mu \mathrm{m}$ while the mean vessel diameter was $105.6 \pm 46.1 \mu \mathrm{m}$; pore diameter was $112.7 \pm 28.8 \mu \mathrm{m}$. Perforation plate simple, inclination oblique to transverse with a tail at one end or absent; pitting simple and alternate.

Axial parenchyma: Paratracheal, aliform-confluent, in bands, more than three cells wide

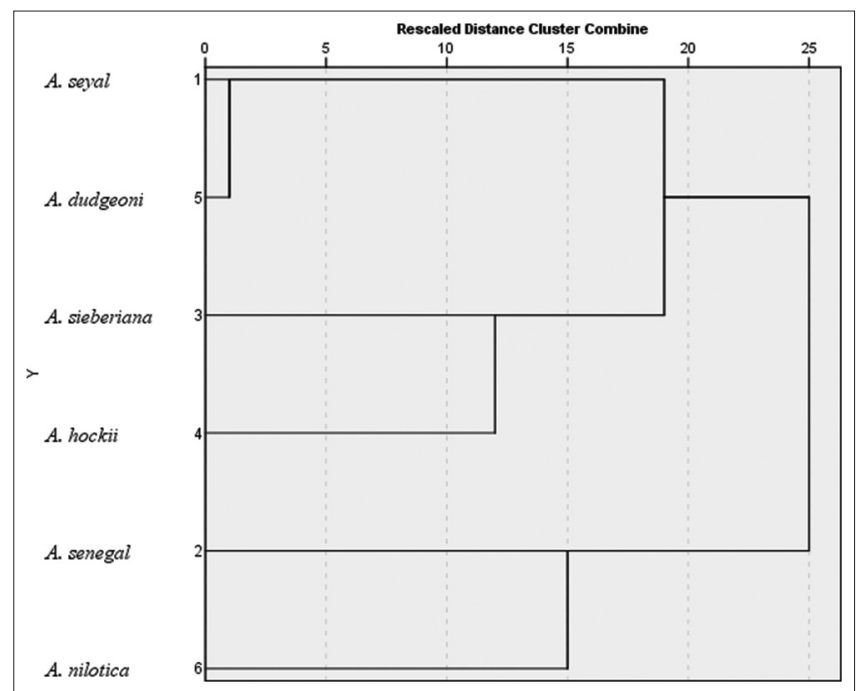

Figure 1: Dendrogram using complete linkage showing taxonomic relationship among six Acacia species studied
Ray: Predominantly multiseriate, few uniseriate or biseriate. Rays, non-storied and heterogeneous (comprising of both procumbent and upright cells). Ray cells circular, polygonal, cylindrical and oval at tangential plane. Mean ray length $381.4 \pm 110.3 \mu \mathrm{m}$ and diameter $52.0 \pm 9.3 \mu \mathrm{m}$.

Fibre: Libriform, non-storied, non-septate; average fibre length $721.2 \pm 155.8 \mu \mathrm{m}$, diameter $23.4 \pm 4.7 \mu \mathrm{m}$, lumen diameter $10.6 \pm 4.5 \mu \mathrm{m}$ and wall thickness $6.4 \pm 1.6 \mu \mathrm{m}$.

Acacia hockii (Figures 2B, 3B, 4B b 5B)

Porosity: Diffuse porous

Vessel: Solitary vessels dominant, radial pore multiple ranged from 2-3 and pore clusters 2-6. Pore shape at transverse plane circular, oval, cylindrical and arch; tyloses present in few vessels. Mean vessel length was $232.8 \pm 44.7 \mu \mathrm{m}$, while the mean vessel diameter was $128.8 \pm 57.0 \mu \mathrm{m}$, pore diameter was $138.1 \pm 27.2 \mu \mathrm{m}$. Perforation plate simple, inclination oblique to transverse with a tail at one end or two tails, one at each end or no tail, pitting simple and alternate.

Axial parenchyma: Paratracheal, aliform-confluent, in bands more than three cells wide.

Ray: Multiseriate and uniseriate rays in equal number. Rays nonstoried and heterogenous (comprising of both procumbent and

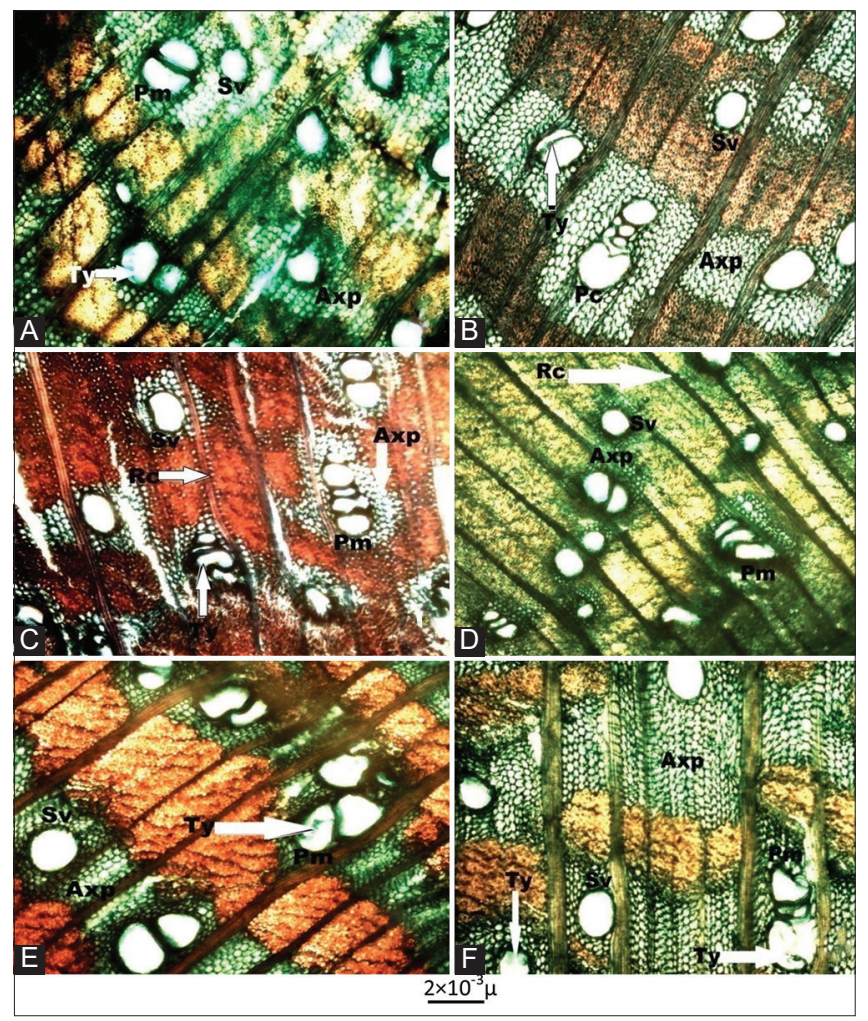

Figure 2: Transverse Sections (TS) of the wood of Acacia species studied. A: A. dudgeoni, B: A. hockii, C: A. nilotica, D: A. senegal, $\mathrm{E}: A$. seyal and $\mathrm{F}$ : A. sieberiana. Legend: Pc-Pore cluster, Pm-Pore multiple, Sv-Solitary vessel, T-Tyloses, Axp-Axial parenchyma 
upright cells). Ray cells are circular, polygonal, cylindrical and oval at tangential plane. Mean ray length was 494.4 $\pm 241.1 \mu \mathrm{m}$ and diameter was $63.4 \pm 14.4 \mu \mathrm{m}$.

Fibre: Libriform, non-storied, non-septate; average fibre length $804.0 \pm 317.3 \mu \mathrm{m}$, diameter $15.4 \pm 3.4 \mu \mathrm{m}$, lumen diameter $6.0 \pm 3.2 \mu \mathrm{m}$ and wall thickness $4.7 \pm 1.3 \mu \mathrm{m}$.

Acacia nilotica (Figures 2C, 3C, 4C \& 5C)

Porosity: Diffuse porous

Vessel: Solitary vessels dominant, radial pore multiple ranged from 2-5 and pore clusters 2-5. Pore shape at transverse plane circular, oval, cylindrical and arch; tyloses present in few

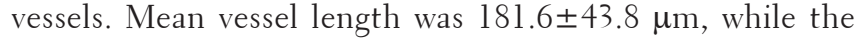
mean vessel diameter was $168.4 \pm 31.6 \mu \mathrm{m}$, pore diameter was $109.3 \pm 25.1 \mu \mathrm{m}$. Perforation plate simple, inclination oblique to transverse with a tail at one end or no tail, pitting simple and alternate

Axial parenchyma: Paratracheal, in bands more than three cells wide, winged aliform and vasicentric

Ray: Predominantly uniseriate with a few biseriate and multiseriate. Rays non-storied and heterogenous (comprising

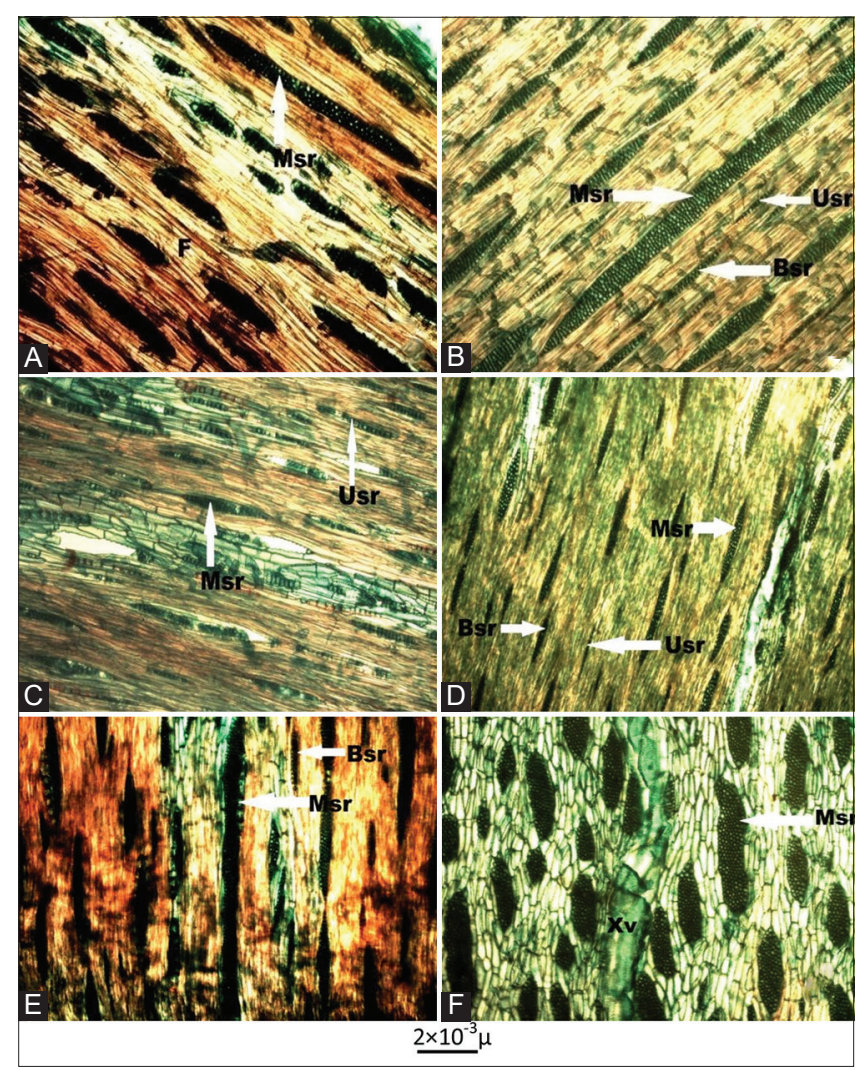

Figure 3: Tangential longitudinal Sections (TLS) of the wood of Acacia species studied. A: A. dudgeon, B: A. hockii, C: A. nilotica, $\mathrm{D}$ : A. senegal, E: A. seyal and F: A. sieberiana (F). Legend: UsrUniseriate ray, Bsr-Biseriate ray, Msr-Multiseriate ray, F-Fibre and Xv-Xylem vessel of both procumbent and upright cells). Ray cells are circular, polygonal, cylindrical and oval at tangential plane. Mean ray length was $452.2 \pm 128.2 \mu \mathrm{m}$ and diameter was $52.0 \pm 9.5 \mu \mathrm{m}$.

Fibre: Libriform, non-storied, non-septate; average fibre length $892.4 \pm 246.1 \mu \mathrm{m}$, diameter $20.5 \pm 3.5 \mu \mathrm{m}$, lumen diameter $9.7 \pm 4.1 \mu \mathrm{m}$ and wall thickness $5.4 \pm 1.4 \mu \mathrm{m}$

A. senegal (Figures 2D, 3D, 4D d 5D)

Porosity: Diffuse porous.

Vessel: Solitary vessels dominant, radial pore multiple ranged from 2-3 and pore clusters 2-4. Pore shape at transverse plane circular, oval, cylindrical and arch; tyloses present in few vessels. Mean vessel length was $214.0 \pm 48.9 \mu \mathrm{m}$, while the mean vessel diameter was $178.8 \pm 43.6 \mu \mathrm{m}$, pore diameter was $103.1 \pm 24.7 \mu \mathrm{m}$. Perforation plate simple, inclination oblique to transverse with a tail at one end or no tail at all, pitting simple and alternate

Axial parenchyma: Paratracheal, confluent and vasicentric

Ray: Predominantly multiseriate with few uniseriate and biseriate. Rays non-storied and heterogenous (comprising of both procumbent and upright cells). Ray cells are circular,

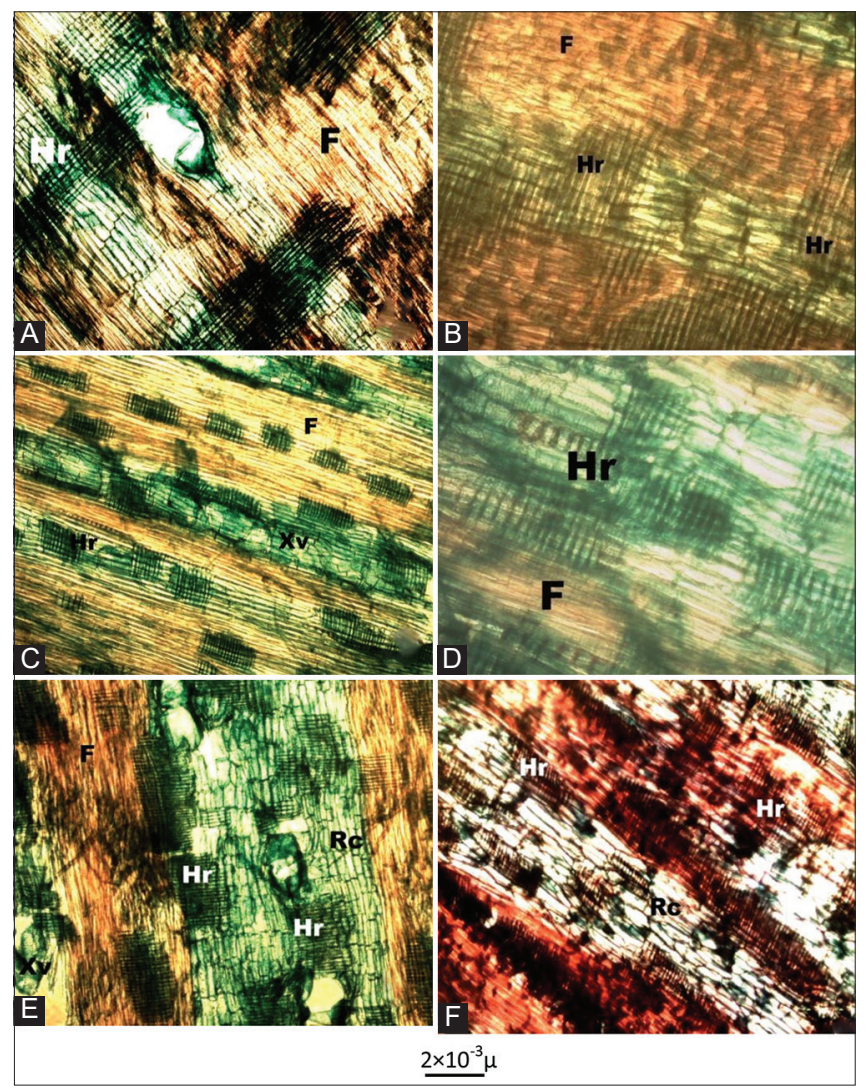

Figure 4: Radial Longitudinal Sections (RLS) of the wood of Acacia species studied. A: A. dudgeon, B: A. hockii, C: A. nilotica, D: A. senegal, $\mathrm{E}$ : A. seyal and F: A. sieberiana. Legend: Hr- Heterogenous ray, RcRay cell, F-Fibre 
polygonal, cylindrical, square and oval at tangential plane. Mean ray length 309.6 $\pm 66.4 \mu \mathrm{m}$ and diameter $(36.0 \pm 7.0 \mu \mathrm{m})$.

Fibre: Libriform fibres non-storied, non-septate; average fibre length $805.6 \pm 153.5 \mu \mathrm{m}$, diameter $19.8 \pm 3.7 \mu \mathrm{m}$, lumen diameter $11.8 \pm 5.3 \mu \mathrm{m}$ and wall thickness $4.0 \pm 1.3 \mu \mathrm{m}$.

Acacia seyal (Figures 1E, 2E, 3E 4E \& 5E)

Porosity: Diffuse porous.

Vessel: Solitary vessels dominant, radial pore multiple ranged from 2-4 and pore clusters 2-6. Pore shape at transverse plane circular, oval, cylindrical, saucer and arch; tyloses present in few vessels. Mean vessel length was $212.0 \pm 50.9 \mu \mathrm{m}$, while the mean vessel diameter was $159.2 \pm 42.1 \mu \mathrm{m}$, pore diameter was $150.1 \pm 24.8 \mu \mathrm{m}$. Perforation plate simple, inclination oblique to transverse with few having a tail at one end, others having no tail at all, pitting simple and alternate.

Axial parenchyma: Paratracheal in bands more than three cells wide, aliform-confluent and vasicentric.

Ray: Predominantly multiseriate with few uniseriate and biseriate. Rays non-storied and heterogenous (comprising of both procumbent and upright cells). Ray cells are circular, polygonal, cylindrical and oval at tangential plane. Mean ray length $453.8 \pm 143.9 \mu \mathrm{m}$ and diameter $51.8 \pm 11.9 \mu \mathrm{m}$.

Fibre: Libriform, non-storied, non-septate; average fibre length $727.6 \pm 217.1 \mu \mathrm{m}$, diameter $16.2 \pm 2.6 \mu \mathrm{m}$, lumen diameter $4.7 \pm 1.7 \mu \mathrm{m}$ and wall thickness $5.8 \pm 1.2 \mu \mathrm{m}$.
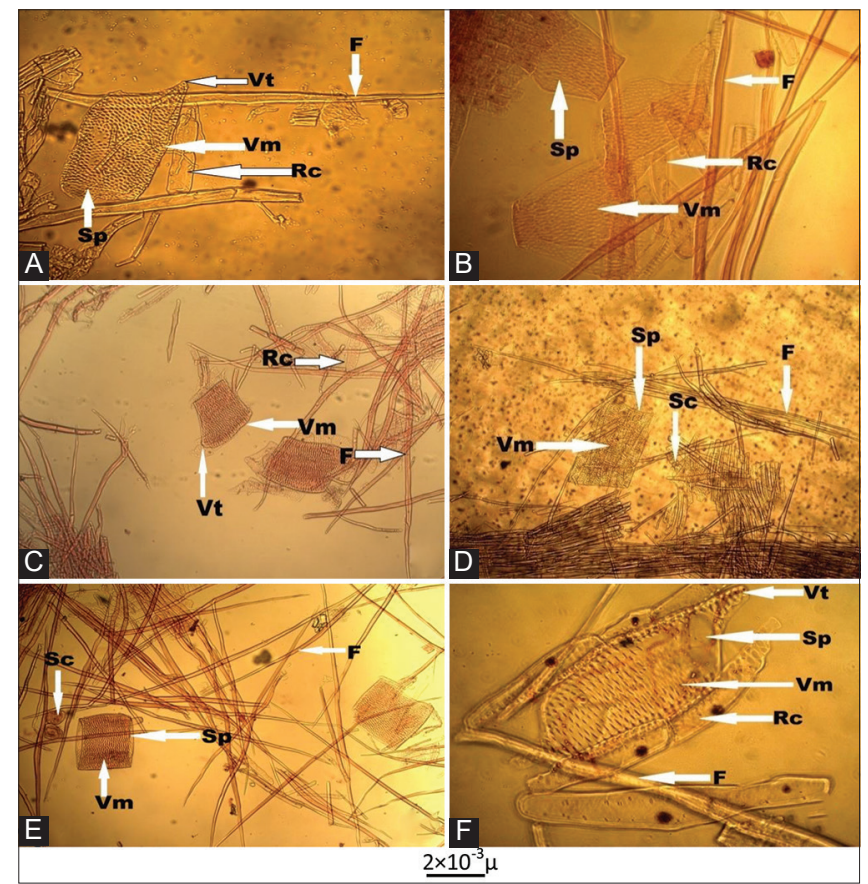

Figure 5: Wood macerates of Acacia species studied. A: A. dudgeon, B: A. hockii, C: A. nilotica, D: A. Senegal, E: A. seyal and $\mathrm{F}$ : A. sieberiana. Legend: F-Fibre, Vm-Vessel member, Vt-Vessel tail, Rc-Ray cell, Sp-Simple perforation and Sc-Sclereids

\section{Acacia sieberiana (Figures $1 F, 2 F, 3 F, 4 F \& 5 F$ )}

Porosity: Diffuse porous.

Vessel: Solitary vessels dominant, radial pore multiple ranged from 2-3 and pore clusters 2-3. Pore shape at transverse plane circular, oval, cylindrical and arch; tyloses present in few vessels. Mean vessel length was $181.2 \pm 39.2 \mu \mathrm{m}$, while the mean vessel diameter was $179.2 \pm 62.2 \mu \mathrm{m}$, pore diameter was $157.9 \pm 33.5 \mu \mathrm{m}$. Perforation plate simple, inclination oblique to transverse with a tail at one end or two tails, one at each end or no tail at all, pitting simple and alternate.

Axial parenchyma: Paratracheal, vasicentric in bands more than three cells wide.

Ray: Predominantly multiseriate with few uniseriate and biseriate. Rays non-storied and heterogenous (comprising of both procumbent and upright cells). Ray cells are circular, polygonal, cylindrical and oval at tangential plane. Mean ray length 386.6 $\pm 90.6 \mu \mathrm{m}$ and diameter $84.2 \pm 18.2 \mu \mathrm{m}$.

Fibre: Libriform, non-storied, non-septate; average fibre length $744 \pm 250.1 \mu \mathrm{m}$, diameter $19.1 \pm 4.3 \mu \mathrm{m}$, lumen diameter $9.5 \pm 2.8 \mu \mathrm{m}$ and wall thickness $4.8 \pm 1.6 \mu \mathrm{m}$.

\section{DISCUSSION}

Wood anatomical data are known to have diverse applications in plant systematics and evolution; such data have been employed in the identification and classification of flowering plants (Herendeen \& Miller, 2000). Evidence from the present study also suggests that in addition to macro-morphological data, wood anatomical data are useful in identifying and delimiting the six Acacia species studied. The diffuse porous wood, dominance of solitary vessels, paratracheal axial parenchyma, occasionally banded axial parenchyma, simple perforation plates and absence of storeyed rays and fibres are unifying characters of the Acacia species. This supports the work of Evans et al. (2006) who reported the above listed characters as the most distinctive anatomical characters of the wood of Acacia sensu lato. The occurrence of tyloses in vessels, though few in the taxa, as reported in this study lay credence to the taxonomic importance of this character as employed by Metcalfe and Chalk (1989) who used presence or absence of tyloses in differentiating the taxa in the family Sterculiaceae. Banded and paratracheal axial parenchyma cells were present in all species except in A. senegal which exhibited strictly paratracheal type, thus diagnostic for the species. All the Acacia species studied had predominantly multiseriate and few uniseriate and biseriate rays except for A. nilotica which had predominantly uniseriate rays with few multiseriate and biseriate rays. This report is in contrast to Mundotiya et al. (2016) who reported predominantly multiseriate rays for A. nilotica. The difference may be attributed to environmental influence which needs to be further investigated in the taxon. The nature of the perforation plate is a character that is important in wood identification because of its conspicuousness (Carlquist, 2001). Simple perforation 
plates were reported in all the species investigated in this study. According to William (1967), the constancy of simple perforation between vessel elements and alternate intravascular pitting, crystal sands and presence of libriform wood fibres indicate a trend towards phylogenetic specialization in some cells and tissues. In spite of the taxonomic value qualitative wood anatomical characters, the importance of the quantitative wood anatomical characters cannot be overlooked. Elongated and narrow vessels are primitive characters while short and wide vessels are advanced characters (Metcalfe \& Chalk, 1950), it may therefore be inferred that A. hockii is the most primitive and A. dudgeoni the most advanced species of all the species considered (Table 3).

The dendrogram of the relationships among the taxa (Figure 1) splits them into two main groups. Group A consists of A. seyal, A. dudgoeni, A. sieberiana, and A. hockii and group B consists of A. senegal and A. nilotica. Acacia seyal and A. dudgeon are very closely related but distantly related to A. sieberiana and A. hockii. Acacia nilotica is also distantly related to A. senegal.

The increasing demand for pulp and paper can only be achieved by sourcing many woody plant species with appreciable fibre characteristics (Oluwadare \& Ashimiyu, 2007). Measurements from the wood macerates of individual species of Acacia were used to obtain the fibre morphological indices such as the Runkel and Slenderness ratios as well as the Flexibility coefficient (Table 3). Acacia nilotica had the longest fibres while A. dudgeoni had the shortest fibres. Fibre length and distribution has been reported to play important roles in the processing and mechanical performance of fiber-based products such as paper and fiberboard (Migneault et al., 2008). The good wood for pulp and paper production is expected to have a Runkel ratio of less or equal to 1 (Kpikpi, 1992). The Runkel ratio of A. senegal $(0.99 \mu \mathrm{m})$ compares favorably to that of Anthonotha macrophylla $(0.99 \mu \mathrm{m})$ and Dialium guineensis $(0.99 \mu \mathrm{m})$ which are hardwood species in the Nigerian rainforest ecosystem (Ezeibekwe et al., 2009), and higher than the reported $0.79 \mu \mathrm{m}$ for tropical Pinus species (Ajala, 1997) and $0.70 \mu \mathrm{m}$ for Dacryodes edulis (Ajuziogu et al., 2010). A good wood suitable for pulping, must have fibres with satisfactory flexibility (Idu \& Ijeomah, 2000). In relation to flexibility ratio, fibres are grouped into four (Betkas et al., 1999); the first group is the high elastic fibres group with elasticity coefficient greater than $75.2 \mu \mathrm{m}$, the second is the elastic fibres group with elasticity coefficient between $50-75 \mu \mathrm{m}$, the third is the rigid fibres group having their elasticity coefficient between $30-50 \mu \mathrm{m}$ and the last is the highly rigid fibres group having elasticity coefficient less than $30 \mu \mathrm{m}$. Considering this classification, the flexibility ratios of A. senegal $(57.08 \mu \mathrm{m})$ and A. sieberiana $(50.18 \mu \mathrm{m})$ are within the elastic fibre group, A. hockii $(37.86 \mu \mathrm{m})$, A. dudgeoni $(44.52 \mu \mathrm{m})$ and A. nilotica $(46.09 \mu \mathrm{m})$ are within the rigid fibres group while only A. seyal $(29.07 \mu \mathrm{m})$ belongs to the highly rigid fibres group (Table 4).

Slenderness ratio of wood signifies the wood's tearing strength. It is the ratio of fibre length to the fibre diameter. The acceptable mean value for slenderness ratio in papermaking is $\geq 33 \mu \mathrm{m}$

Table 3: Quantitative anatomical characters of the Acacia Species studied

\begin{tabular}{|c|c|c|c|c|c|c|}
\hline NAME & A. hockii & A. $d u d g e o n$ & A. seyal & A. nilotica & A. senegal & A. sieberiana \\
\hline \multirow[t]{2}{*}{ Fibre length $(\mu \mathrm{m})$} & $410-1430$ & $450-1090$ & $350-1260$ & $250-1450$ & $490-1090$ & $260-1390$ \\
\hline & $804.0 \pm 317.3$ & $721.2 \pm 155.8$ & $727.6 \pm 217.1$ & $892.4 \pm 246.1$ & $805.6 \pm 153.5$ & $744 \pm 250.1$ \\
\hline \multirow[t]{2}{*}{ Fibre diameter $(\mu \mathrm{m})$} & $10.0-22.5$ & $17.5-40.0$ & $12.5-22.5$ & $12.5-27.5$ & $12.5-27.5$ & $12.5-30.0$ \\
\hline & $15.4 \pm 3.4$ & $23.4 \pm 4.7$ & $16.2 \pm 2.6$ & $20.5 \pm 3.5$ & $19.8 \pm 3.7$ & $19.1 \pm 4.3$ \\
\hline Fibre lumen & $2.5-12.5$ & $5.0-25.0$ & $2.5-10.0$ & $2.5-22.5$ & $2.5-22.5$ & $5.0-15.0$ \\
\hline diameter $(\mu \mathrm{m})$ & $6.0 \pm 3.2$ & $10.6 \pm 4.5$ & $4.7 \pm 1.7$ & $9.7 \pm 4.1$ & $11.8 \pm 5.3$ & $9.5 \pm 2.8$ \\
\hline Fibre wall & $2.5-7.5$ & $5.0-10.0$ & $5.0-7.5$ & $2.5-7.5$ & $2.5-5.0$ & $2.5-7.5$ \\
\hline thickness $(\mu \mathrm{m})$ & $4.7 \pm 1.3$ & $6.4 \pm 1.6$ & $5.8 \pm 1.2$ & $5.4 \pm 1.4$ & $4.0 \pm 1.3$ & $4.8 \pm 1.6$ \\
\hline \multirow[t]{2}{*}{ Vessel length $(\mu \mathrm{m})$} & $140-320$ & $100-380$ & $150-360$ & $100-250$ & $140-330$ & $110-270$ \\
\hline & $232.8 \pm 44.7$ & $216.4 \pm 80.5$ & $212.0 \pm 50.9$ & $181.6 \pm 43.8$ & $214 \pm 48.9$ & $181.2 \pm 39.2$ \\
\hline \multirow[t]{2}{*}{ Vessel diameter $(\mu \mathrm{m})$} & $30-210$ & $50-230$ & $90-230$ & $110-220$ & $100-260$ & $40-280$ \\
\hline & $128.8 \pm 57.0$ & $105.6 \pm 46.1$ & $159.2 \pm 42.1$ & $168.4 \pm 31.6$ & $178.8 \pm 43.6$ & $179.2 \pm 62.2$ \\
\hline \multirow[t]{2}{*}{ Ray length $(\mu \mathrm{m})$} & $260-1770$ & $180-650$ & $270-820$ & $230-760$ & $200-490$ & $230-700$ \\
\hline & $494.4 \pm 241.1$ & $381.4 \pm 110.3$ & $453.8 \pm 143.9$ & $452.2 \pm 128.2$ & $309.6 \pm 66.4$ & $386.6 \pm 90.6$ \\
\hline \multirow[t]{2}{*}{ Ray diameter $(\mu \mathrm{m})$} & $40-100$ & $30-70$ & $30-70$ & $40-70$ & $30-60$ & $50-120$ \\
\hline & $63.4 \pm 14.4$ & $52.0 \pm 9.3$ & $51.8 \pm 11.9$ & $52.0 \pm 9.5$ & $36 \pm 7.0$ & $84.2 \pm 18.2$ \\
\hline \multirow[t]{2}{*}{ Pore diameter $(\mu \mathrm{m})$} & $75-185$ & $57.5-190$ & $82.5-197.5$ & $50-162.5$ & $62.5-162.5$ & $87.5-237.5$ \\
\hline & $138.1 \pm 27.2$ & $112.7 \pm 28.8$ & $150.1 \pm 24.8$ & $109.3 \pm 25.1$ & $103.1 \pm 24.7$ & $157.9 \pm 33.5$ \\
\hline
\end{tabular}

Mean \pm standard deviation

Table 4: Fibre Morphological indices and biometrical coefficient of Acacia Species

\begin{tabular}{lcccccc}
\hline Fibre Indices & A. hockii & A. dudgeon & A. seyal & A. nilotica & A. Senegal & A. sieberiana \\
\hline Runkel ratio $(\mu \mathrm{m})$ & $0.33-4.00$ & $0.60-3.00$ & $1.00-6.00$ & $0.22-4.00$ & $0.22-4.00$ & $0.40-3.00$ \\
& $2.14 \pm 1.32$ & $1.46 \pm 0.82$ & $2.84 \pm 1.40$ & $1.39 \pm 0.83$ & $0.99 \pm 0.85$ & $1.11 \pm 0.57$ \\
Flexibility ratio $(\mu \mathrm{m})$ & $20.00-75.00$ & $25.00-63.64$ & $14.29-57.14$ & $20.00-81.8246 .09 \pm 14.14$ & $20.00-81.82$ & $25.00-71.43$ \\
& $37.86 \pm 16.20$ & $44.52 \pm 12.78$ & $29.07 \pm 9.15$ & & $57.08 \pm 18.23$ & $50.18 \pm 11.32$ \\
Slenderness ratio $(\mu \mathrm{m})$ & $24.57-122.00$ & $17.45-49.14$ & $22.0-100.00$ & $9.09-83.20$ & $21.82-80.00$ & $17.78-76.00$ \\
& $54.34 \pm 24.93$ & $31.46 \pm 7.26$ & $45.78 \pm 15.58$ & $44.87 \pm 14.24$ & $42.78 \pm 14.19$ & $40.13 \pm 14.61$ \\
\hline
\end{tabular}

Mean \pm standard deviation 
(Xu et al., 2006). All selected species had high slenderness ratio except A. dudgeoni $(29.07 \mu \mathrm{m})$. These differences have important roles in the strength and mechanical properties of wood for various uses.

\section{CONCLUSION}

Acacia senegal is recommended as a good material for pulp and paper production due to its appreciable Runkel ratio $(0.99 \mu \mathrm{m})$, Flexibility ratio $(57.08 \mu \mathrm{m})$ and slenderness ratio $(42.78 \mu \mathrm{m})$. However, the utilization potential of this species will be enhanced if its pulp is combined with other pulpable wood species like Gmelina arborea Roxb. which has a Runkel ratio of $0.25 \mu \mathrm{m}$ to achieve desirable pulp and paper yield.

\section{ACKNOWLEDGEMENT}

Our sincere thank goes to Mr. Chukwuma E. C. of Forest Institute of Nigeria, Ibadan, Oyo State, who assisted us in the collection of the plant samples used in this work.

\section{REFERENCES}

Ajala, O. O. (1997). Evaluation of wood and fibre characteristics of nigerian grown Pinus carribaea. Department of Forest Resources Management, University of Ibadan, Ibadan, Nigeria.

Ajuziogu, G. C., Nzekwe, U., \& Chukwuma, H. I. (2010). assessment of suitability of fibres of four nigerian fruit trees for paper-making, Bio-Research, 8(2), 679-681.

Bennie, L., Coetzee, J., Malan, E., \& Woolfrey, J. R., \& Ferreira, D. (2001). Oligomeric Flavanoids. Part 34: Doubly-linked Proteracacinidin analogues from Acacia caffra and Acacia ga/pinii. Tetrahedron, 57(4), 661-667. https://doi.org/10.1016/S0040-4020(00)01036-X

Betkas, I., Tutus, A., \& Eroglu, H. (1999). A study of the suitability of Pinus brutiaten (Calabrian pine), for pulp and paper manufacture. Turkish Journal of Agriculture and Forestry, 23, 589-599.

Carlquist, S. (2001). Comparative wood Anatomy; systematics, ecological and evolutionary aspects of dicotyledon wood. $\left(2^{\text {nd }}\right.$ ed. $)$. Berlin: Springer.

Cronquist, A. (1981). An integrated system of classification of flowering plants (pp. 592-595). New York: Columbia University.

Evans, J. A., Gasson, P. E., \& Lewis, G. P. (2006). Wood anatomy of the Mimosoideae (Leguminosae). (IAWA Journal, Supplement 5). Leiden, the Netherlands, IAWA, 117.

Ezeibekwe, I. O., Okeke, S. E., Unamba, C. I. N., \& Ohaeri, J. C. (2009). An investigation into the potentials of Dactyladenia bacteri; Dialum guineense; and Anthonota macrophylia for Paper Pulp Production.
Report and Opinion, 1(4), 18-25.

Flath, R. A., Mon, T. R., Lorenz, G., Whitten, C. J., \& Mackley, J. W. (1983). volatile components of Acacia sp. Blossoms. Journal of Agricultural and Food Chemistry, 31(6), 1167-1170. https://doi.org/10.1021/ jf00120a008

Herendeen, P. S., \& Miller, R. B. (2000). Utility of wood anatomical characters in species in the sub-genus Leptostemonum (BITT) DUN. Glimpses in Plant Research, 12, 73-86.

IAWA. (1989). Hardwood features list: definitions and illustration. IAWA Bulletin, 10(3), 219-332. https://doi.org/10.1163/2294193290000247

Idu, M., \& ljeomah, J. U. (2000). Wood anatomy of some savannah fabaceae species: dimensional variation in fibre and vessel element of Daniellia oliverii (Rolfe) Hutch \& Dalz. Indian Forester, 126(2), 149-153.

Kpikpi, W. M. (1992). Wood structure and paper making potentials of Ricinodendron heudelotii and Albizia zygia in relation to Gmelina arborea in Nigerian. Journal of Botany, 5, 41-50.

Krisdianto, K., \& Damayanti, R. (2007). Anatomical properties and fiber dimension of prickly Acacia (Acacia nilotica L.) from Balusan National Park. Indonesian Journal of Forestry Research, 4(2), 93-103. https:// doi.org/10.20886/ijfr.2007.4.2.93-103

Malan, E., \& Roux, D. G. (1975). Flavonoids and tannins of Acacia Species. Phytochemistry, 14(8), 1835-1841. https://doi.org/10.1016/00319422(75)85306-4

Metcalfe, C. R., \& Chalk, L. (1950). Anatomy of the Dicotyledons: Leaves, stem, and wood in relation to taxonomy (pp. 476-487). Oxford: Clarendon Press

Metcalfe, C. R., \& Chalk, L. (1989). Anatomy of the Dicotyledons (Vol. 2, pp. 98-116). ( $2^{\text {nd }}$ ed.). Oxford: Clarendon Press.

Migneault, S., Koubaa, A., Erchiqui, F., Chaala, A., Englund, K., Krause, C., \& Wolcott, M. (2008). Effect of fiber length on processing and properties of extruded wood-fiber/HDPE composites. Journal of Applied Polymer Science 110:1085-1092. https://doi.org/10.1002/app.28720

Mundotiya, A., Dash, R., Gupta, S., \& Chandan, J. (2016). Anatomy of family mimosoideae from different geographical areas. International Research Journal of Biological Science, 5(3), 1-10.

Oluwadare, A. O., \& Ashimiyu, O. S. (2007). The relationship between fibre characteristics and pulp-sheet properties of Leucaena leucocephala (Lam.) De Wit. Middle-East. Journal of Scientific Research, 2(2), 63-68.

Saini, M. L., Saini, R., Roy, S., \& Kumar, A. (2008). Comparative pharmacognostical and antimicrobial studies of Acacia species (Mimosaceae). Journal of Medicinal Plants Research, 2(12), 378-386.

Secor, J. B., Conn, E. E., Dunn, J. E., \& Seigler, D. S. (1976). Detection and identification of cyanogenic glucosides in six species of Acacia. Phytochemistry, 15(11), 1703-1706. https://doi.org/10.1016/S00319422(00)97460-0

Seigler, D. S. (2003). Phytochemistry of Acacia - sensu lato. Biochemical Systematics and Ecology, 31(8), 845-873. https://doi.org/10.1016/ S0305-1978(03)00082-6

William, L. S. (1967). Kleinodendron and Xylem Anatomy of Cluytieae (Euphorbiaceae) American Journal of Botany, 54(6), 663-676. https:// doi.org/10.2307/2440943

Xu, F., Zhong, X. C., Sun, R. C., \& Lu, Q. (2006). Anatomy, ultra structure and lignin distribution in cell wall of caragana korshinskii. Industrial Crops \& Products, 24(2), 186-193. 